\title{
IS THE RELATIONSHIP BETWEEN FINANCIAL TECHNOLOGY AND CREDIT RISK MONOTONIC? EVIDENCE FROM THE BRICS ECONOMIES
}

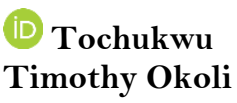

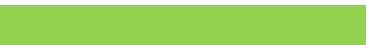

Article History

Received: 26 June 2020 Revised: 30 July 2020

Accepted: 2 September 2020

Published: 18 September 2020

Keywords

Credit risk

Financial technology

Macroeconomic factors

Bank-specific factors

GDP growth

BRICS economies.

JEL Classification:

C23; G00; G21; F41.

\author{
Postgraduate Student, Department of Economics, University of Zululand, \\ South Africa and Economic Department, Federal University Oye-Ekiti, \\ Nigeria. \\ Email: tochukwu.okoli@fuoye.edu.ng.Tel:+27732813589
}

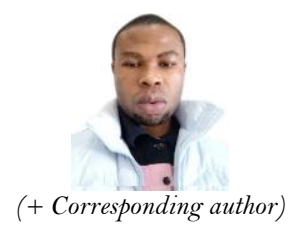

\section{ABSTRACT}

This study employed the panel ARDL $(1,1)$ pooled mean group, mean group and dynamic fixed effect estimators to investigate the relationship between financial technology (Fintech) and bank credit risk measured in terms of nonperforming loan to total loan (NPL) among the BRICS (Brazil, Russia, India, China and South Africa) economies over the 1995-2018 period. The study made a novel contribution to Fintechs' data series by generating an indicator for Fintech using the principal component analysis. The findings reveal a consistent result with previous studies that both macroeconomic and bank-specific factors drive credit risk. We also found a nonlinear relationship between Fintechs and credit risk. The U-shaped relationship between Fintechs and NPL revealed that BRICS economies face a dampening impact of Fintech on NPL to a certain threshold after which further adoption of Fintechs will significantly raise credit risk. The robustness checks of the dynamic panel Generalized Methods of Moments (GMM) and the fixed effect models also revealed a consistent conclusion. We recommend the optimization of the right Fintech adoption with bank collaboration among the BRICS economies.

Contribution/ Originality: This study contributes to the exiting literature by using a new estimation methodology-PCA to generate a Fintech index. The analysis revealed that Fintech among the BRICS is more susceptible to changes in mobile cellular subscription/mobile banking. The study therefore concludes that credit risk could be worsened with too many fintech adoptions.

\section{INTRODUCTION}

The need to identify the factors that drives banking crisis has intensified since the global financial crisis of 2008/09, and it has become more critical with the advent of financial technology (Fintech). Recent financial crisis has raised concerns on the consequences that banking system instability can have on an economy (Agnello \& Sousa, 2011); however, the unanswered question is whether Fintech will lead to higher credit crisis and possibly another global financial crisis. It therefore becomes imperative to investigate this link in the light of the evolving global macroeconomic and financial conditions.

Aside the fact that macroeconomic and bank factors have been found to play important roles in determining the level of banking credit crisis (Demirgüç-Kunt \& Detragiache, 1998; Llewellyn, 2002) we thought it would be very necessary to also assess its Fintechs' disruptive impact, especially in regions with high Fintechs adoption rate, such 
as the BRICS (Brazil, Russia, India, China and South Africa) economies (Ernest \& Young, 2017). This study hypothesizes that since Fintechs start-ups extend and manage credits like traditional banks, it (Fintech) can have an asymmetric impact on bank credit risk in two ways. Firstly, it can reduce bank credit risk by providing alternative sources of finance to potential loan defaulters, thereby enabling them to offset their accounts with their banks. The extent to which Fintech can reduce bank credit risk can be greater if these technologies emanate from within the banking sector and/or there is a reasonable collaboration established between banks and Fintech companies. Secondly, it can also raise bank credit risk because of its low interest rate competitive advantage over banks high interest laden loans. Moreover, Fintech's convenience in loan extension, given their clients greater value for their money could as well raise bank credit risk by reducing banks' loan request and even its repayment. Hence, a situation where Fintechs may reduce credit risk at sometimes and raises it at other times and vice versa might arise.

On the other hand, banking crisis may also arise when banks are struggling with liquidity and/or insolvency problems (Castro, 2013). This implies that banks' vulnerability to Fintechs adoption might not only be limited to credit risk but also to its ability to earn income (Profit Risk) and continuously pay its current obligations by meeting unexpected withdrawals (Liquidity risk). This is because Fintechs also provide alternative source of funds through its peer-to-peer lending and crowd-funding channels which can expose banks to high liquidity and income risks. Moreover, Demirgüç-Kunt and Detragiache (1998) assert that adverse economic conditions, such as rising unemployment, low or negative growth rates, with high levels of interest rates and high inflation can spur higher banking crises. These views buttress the fact that both bank-specific and macroeconomic factors drives credit risk. Hence, it becomes evident that banking crisis is always triggered by an interaction of economic (macroeconomic factors), financial (bank specific factors) and structural (Fintechs factor) weaknesses (Llewellyn, 2002).

\section{LITERATURE REVIEW}

Empirical literature is replete with studies that centered on the bank specific and macroeconomic factors that determine credit risk. Chaibi and Ftiti (2015) categorized these determinants into two broad areas, they are systemic and un-systemic determinants. While the systemic credit risks are driven by macroeconomic variables, the un-systemic determinants are bank-specific factors (Louzis, Vouldis, \& Metaxas, 2012). To be more specific, a number of studies concentrated on the macroeconomic determinants of credit risk such as the growth rate of GDP, interest rate, exchange rate, inflation rate, employment rate and stock index. Others looked at basically the bankspecific/microeconomic determinants such as banks' managerial competency, efficiency indicators. More also, there is a mid-course attempt that considered the combined effects of both indicators on credit risk.

To start with, studies on the impact of macroeconomic variables on credit risk such as the work of (Castro, 2013) employed a dynamic panel approach to investigate this link for Greece, Ireland, Portugal, Spain and Italy economies. His result follows the prior expectation that credit risk is inversely related with GDP growth, the share of housing price indices and credit risk, but is directly connected with interest rate, unemployment rate, credit growth and real exchange rate. Similar conclusion was also reached by Nkusu (2011) after exploring how macroeconomic developments affect nonperforming loans (credit risk) among 26 advanced economies. Likewise, several other studies such as Festic, Kavkler, and Repina (2011); Kattai (2010); Bonfim (2009); Aver (2008); Bohachova (2008) and Jakubík (2007) lend credence to the fact that macroeconomic factors drive credit risk.

A general finding across these studies is that GDP growth rates, interest rate, inflation rate, unemployment rate, foreign exchange rates, rates of public and private spending and saving, and monetary magnitudes are the main macroeconomic variables that impact credit risk (Altıntas, 2012). However, Altıntas (2012) added that the effect of these variables varies across countries and sectors. This implies that although macroeconomic factors might not be country specific in impacting on credit risk, their degree or extent of impact may differ from one country to another. This argument was empirically strengthened by Ali and Daly (2010) who used a logit model for 
the US and Australian economies and found that although macroeconomic factors impacts on credit risk, their degree of impact was stronger on the US economy than the Australian.

On the other hand, very few studies concentrate on the microeconomic/bank-specific factors that drive the unsystemic credit risk. A notable study by Podpiera and Weill (2008) among the Czech banks used the generalized methods of moment (GMM) dynamic panel estimation technique to find that deteriorations in banks' efficiency trigger higher credit risk among Czech banks. Likewise, Ahmad and Ariff (2007) also investigate this relationship in a comparative array of developed (Australia, France, Japan and USA) and emerging (India, Korea, Malaysia, Mexico and Thailand) markets. Their findings were consistent with that of Berger and DeYoung (1997) on the importance of regulatory capital among the banking systems in the developed economies that offers a range of products whereas managerial competency was the main factor that drives credit risk within the emerging ones.

The combined impact of macroeconomic and bank specific variables on credit risk were assessed by Chaibi and Ftiti (2015). They used a dynamic panel GMM estimation technique for a market-based economy of France and a bank-based economy of Germany for the period 2005-2011. Their results indicate that with the exception of inflation rate, credit risk measured in terms of the ratio of nonperforming loans to total loans (NPL) is influenced by set of macroeconomic variables and that the market-based economy of France is more vulnerable to bank-specific determinants than Germany. Messai and Jouini (2013) and Louzis et al. (2012) strongly emphasised on the dampening impact of growth and bank profitability on credit crisis. They also stress the impact that both macroeconomic variables and some efficiency indicators of bank performance can have on credit risk. This finding is consistent with a later study by Zribi and Boujelbegrave (2011) who estimate a panel model for ten Tunisian commercial banks over the period 1995-2008 and found evidence to support the earlier work of Louzis et al. (2012). Although both systemic and un-systemic factors drive bank credit crisis, bank-specific variables can serve as early warning signal for potential credit risk problem (Salas \& Saurina, 2002).

From the review of the literature, the following conclusions can be. Firstly, both macroeconomic and microeconomic factors influence credit risks. They include the growth rate, share price indices, inflation rate, profitability of banks, and non-interest income of banks, interest rate and unemployment rate. Secondly, authors such as Castro (2013) and Chaibi and Ftiti (2015) believes that aside from interest rate and unemployment rate that raises it, other variables dampens it. They further asserted that the impact of exchange rate depends on some inherent features of the economy being modeled.

While empirical works have focused on identifying the macroeconomic and bank specific variables that can have impact on credit risk, none based on pieces of literature reviewed has assessed its Fintechs disruptive impact, neither has any investigated a threshold effect of Fintechs on credit risk in the Long-run, especially as a substantial increase in credit risk was found during the recent financial crisis period (Castro, 2013). This study aims to fill this gap in the literature and investigate any possible monotonic relationship between Fintechs and credit risk.

\section{SCOPE OF THE STUDY AND DATA DESCRIPTION}

The analysis centers on BRICS (Brazil, Russia, India China and South Africa) economies for the period of 1995 to 2018. There are two basic factors that informed the choice of these economies. One, they rank the highest in Fintechs adoption in the globe (Ernest \& Young, 2017) and secondly, most of them are currently facing intense credit and liquidity issues (South Africa Reserve Bank, 2016). The data used in this study were sourced from the World Bank database. Having established in the literature that both macroeconomic and bank-specific variables drive credit risk, we combine both sets of variables with the inclusion of Fintechs indicator to estimate their combined impact on credit risk. The dependent variable which is the Credit Risk is measured as the ratio of nonperforming loan to total loan (NPL). It captures the extent of loan default by borrowers as credit expansion will most likely lead to higher risk of future defaulters. 


\subsection{Bank-Specific Variables}

Bank Profitability: The more banks' performance and efficiency level improves, the less likely they will issue risky loans. Past performance reflects high quality of management (Louzis et al., 2012). We therefore expect bank profitability measured in terms of Bank Returns to Equity Ratio (ROE) to have a negative effect on Credit risk.

Non-Interest Income: Banks use this to diversify their earning network instead of depending only on interest bugged high risky loans. This indicator as used by Louzis et al. (2012) and Chaibi and Ftiti (2015) is measured by the ratio of non-interest income to total income (NITI).

Capital Adequacy: As long as banks continue to maintain a viable confidence of its depositors, their profit margin will continue to rise. A rising profit margin will detract from potential losses arising from doubtful loans, thereby minimizing credit risk (NPL). Therefore an inverse relationship with credit risk is expected. It will be measured as Bank Capital to Assets Ratio.

\subsection{Macroeconomic Variables}

GDP Growth: Since empirical evidence suggests that business cycle impacts on credit risk, we will include it to account for macroeconomic cycle. During periods of economic boom, borrowers and lenders have sufficient money to settle their account, unemployment is reduced and loan default is minimized. Hence a negative relationship is expected between GDP growth (GDPR) and credit risk (NPL).

Interest Rate: Economic theory on interest rate and liquidity stressed that a rise in interest rate culminates to higher debt burden on borrowers. As borrowers default to pay, due to an increase in interest rate, the level of credit risk (NPL) will rise, hence we expect the impact of interest rate on credit risk to be positive.

Financial Technology: This is the innovated use of modern technology to access and deliver financial services. It is more efficient than the conventional banking style because of its high time value of money, speed and accuracy. Since Fintechs can extend credit and ensure payment compliance faster, it seems it can minimize risks inherent in loan default at least during the short-run. However, there is a possibility that Fintechs will raise credit risk in the long-run if those borrowers begin to trade-off potential losses with bank loans. Therefore the need to investigate not only how of Fintechs impacts on credit risk but also to verify if this impact is monotonic in the phase of changing macro and microeconomic factors becomes imperative.

\subsection{Data and Measurement of Financial Technology}

Although Fintechs have not been pinned down to a particular standard measure, given that they are new innovation in the field of finance, however, for the sake of this study, an index was used to capture it. The difficulty in constructing an index or using a proxy to capture Fintechs is anchored on its various outlets and start-up, most of which keeps evolving as the day goes by; more so, as some of these outlets are not already in a comprehensive long data range. Fintechs is actually a robust indicator in that it cuts across both financial and non-financial institutions. Therefore one indicator or measure will underestimate this variable. We circumvent this challenge by using basic financial innovated technologies through which Fintechs operates; such as the Automated Teller Machine (ATM) per 100,000 people, mobile cellular subscription, and percentage of individuals using internet to total population, and follow the works of Campos and Kinoshita (2010) and Samargandi, Fidrmuc, and Ghosh (2015) to construct an aggregate indicator for Fintechs as a component variable. This was done with the technique of Principal Component Analysis (PCA). The generated index was termed as FTCH.

Table-1. Principal component analysis for financial technology index.

\begin{tabular}{c|c|c|c|c|c|c|c|c|c}
\hline \multicolumn{4}{c|}{ Principal components/correlation } & \multicolumn{4}{c}{ Principal components (eigenvectors) } \\
\hline Component & E. value & Difference & Proportion & Cumulative & Variable & Comp1 & Comp2 & Comp3 & Unexplained \\
\hline Comp1 & 1.966 & 1.028 & 0.655 & 0.655 & ITB & 0.694 & -0.057 & -0.718 & 0 \\
\hline Comp2 & 0.938 & 0.842 & 0.313 & 0.968 & MCS & 0.335 & 0.908 & 0.251 & 0 \\
\hline Comp3 & 0.096 &. & 0.032 & 1.000 & ATM & 0.637 & -0.414 & 0.650 & 0 \\
\hline
\end{tabular}


We then justify this indicator on certain assessment criteria. Firstly, users of Fintechs that operate with eWallet money transfers, Bit-coin, Blockchain technology, etc. uses the mobile subscription and Internet services, therefore including both indicators might lead to a multicollinearity problem especially as our analysis reveals that there is a high correlation between these variables (see appendix). Secondly, neither empirical evidence nor the different databases have come up with any yardstick or an index for measuring Fintechs in part nor in whole, hence, there has not been a uniform consistent proxy that is most appropriate to capture the behaviour of this variable. We believe that this index is a progress in the area of finance to pin down what will represent Fintechs especially as it captures information on every online financial activities for which Fintechs is based. The PCA result and its predicators are presented in Table 1.

The table above reveals that three components make up the Fintechs indicator (FTCH). The first component accounts for about $65.5 \%$ variations of the dependent variable while the second and third components explain about $31.3 \%$ and $3.2 \%$ of it respectively. Therefore the first principal component has the highest explanatory strength. This is confirmed with their respective variable contributions to the components which reveal that financial technology is more susceptible to changes in Internet usage than changes in mobile subscription and use of ATM.

\section{METHODOLOGY AND ECONOMETRIC MODEL}

The estimation technique employed in this study is the panel ARDL bound testing methodology. This is because aside the fact that the data is a mixture of $\mathrm{I}(1)$ and $\mathrm{I}(0)$ series, the time-variant characteristics is very small (twenty-four years) as well as the cross sectional identity (five countries). Pesaran., Shin, and Smith (1999) believe that ARDL works more efficiently when the time series and/or the cross-sectional identities are small.

Moreover, the static fixed and random effects models will not be efficient due to its assumptions of common slopes and variance, but specific intercepts for a fixed effect; and the assumption that the error terms are uncorrelated with the past, present and future values, known as strict exogeneity, Arellano (2003) for the random effect model. Moreover, Loayza and Ranciere (2006) argues that a static panel estimator do not capture the panel dimension of the data by not distinguishing between the short and long-run relationships.

Also this ARDL was preferred above the dynamic Generalized Methods of Moments (GMM) because a GMM technique tends to be inefficient when the cross-sectional identity $(\mathrm{N})$ is less than the time period (T). Given that our series is made up of small $(\mathrm{N}=5)$ and relatively large $(\mathrm{T}=24)$, a dynamic GMM estimators are likely to produce spurious results because small $(\mathrm{N})$ might lead to unreliable autocorrelation whereas the larger the time, the number of instruments gets larger too (Roodman, 2006). However, the dynamic GMM and static fixed and random effects models will still be adopted for robustness check. The need for a dynamic difference GMM model is necessitated on the basis that previous period's credit risk can drive current credit risk.

\subsection{Model Specification}

The econometric model to be estimated follows the Pesaran. et al. (1999) assertion that the dynamic heterogeneous panel regression can be incorporated into an error correction model using the Autoregressive Distributed lag (ARDL) (p, q) approach thus:

$$
\Delta y_{i t}=\delta_{i}\left[y_{i, t-1}-\lambda_{i}^{\prime} X_{i, t}\right]+\sum_{j=1}^{p-1} \eta_{j}^{i} \Delta y_{i, t-j}+\sum_{j=0}^{q-1} \beta_{i j}^{\prime} \Delta X_{i, t-j}+\varphi_{i}+\varepsilon_{i t}
$$

Where $\Delta$ is the difference operator, $y_{i t}$ is the Credit Risk (NPL), $\mathrm{X}$ is a set of independent variables as outlined above including financial technology indicator and a squared of it, $\eta$ and $\beta$ represent the lagged short-run coefficients of the dependent and independent variables respectively, $\lambda$ are the long-run coefficients, and $\delta_{i}$ is the coefficient of the speed of adjustment to long-run steady state. The subscripts $i$ and $t$ represent country and time identities respectively. We will therefore estimate Equation 1 using three different estimators: Pooled Mean Group 
(PMG), Mean Group (MG) and Dynamic Fixed Effect (DFE) because they consider the long-run dynamic adjustment process and the heterogeneity in the model (Demetriades \& Siong, 2006). With emphasis on having consistent and efficient estimates in the long-run, the ARDL model ensures an efficient and consistent parameter estimates irrespective of possible endogeneity due to the presence of lags of dependent and independent variables (Pesaran. et al., 1999).

Moreover, given that each of these estimators possesses some peculiar strengths and weaknesses, the need to explore this is necessary for a better model. Take for instance; the PMG assumes strictly homogenous long-run slope coefficients whereas the short-run coefficients, the intercept, error variance and the adjustment term to longrun steady-state are assumed to be heterogeneous across the cross-sectional units $(\mathrm{N})$. This model seems to work best if there is a common characteristic inherent among the $(\mathrm{N})$ units in the long run even though their short-run adjustment term to steady-state may differ due to peculiar short-run traits such as external shocks, response to policy measures, vulnerability to financial crisis among others. The model is therefore termed valid, consistent and efficient if the error correction term is significantly negative but not lower than negative two (-2), its residual not serially correlated, and the regressors are strictly exogenous.

On the other hand, the Mean Group technique developed by Pesaran and Smith (1995) allows all coefficients to be heterogeneous both in the long and short-runs. Here, the condition for validity, consistency and efficiency of the model will not hold if the data series is not sufficiently large both in its cross-sectional $(\mathrm{N}=5)$ and time identities $(\mathrm{T}=24)$ as were the case in our data. This can make the MG to lack degrees of freedom. Finally, the DFE is somewhat similar to the PMG except that it further restricts the adjustment coefficient and the short-run coefficients with specific intercepts for individual cross-sectional unit. The Hausman test was used to select the best model after estimation for policy recommendation ${ }^{1}$.

\section{RESULTS AND DISCUSSION}

We began the presentation of results with preliminary tests that justify the use of the panel ARDL model such as the unit root test and the correlation analysis to ascertain that our series is a combination of only $\mathrm{I}(0)$ and $\mathrm{I}(1)$ and that there is no presence of perfect exactness or multicollinearity in the model. We employ two different types of panel unit root tests: (1) the Levin, Lin and Chu, and (ii) Im, Pesaran and Shin. Although Pesaran and Smith (1995) and Pesaran. et al. (1999) agrees that the order of integration of variables is not important when applying the panel ARDL model as long as the variables of interest (NPL and FTCH) are I(0) and I(1); however, we carry out this test to ensure that none is $\mathrm{I}(2)^{2}$.

Table-2. Unit root test results.

\begin{tabular}{c|c|c|c|c}
\hline Variables & \multicolumn{2}{|c|}{ IPS Test } & \multicolumn{2}{c}{ LLC Test } \\
\hline & Level & $\mathbf{1}^{\text {st }}$ Difference & Level & $\mathbf{1}^{\text {st }}$ Difference \\
\hline NPL & Stationary & NA & Stationary & NA \\
\hline ROE & Stationary & NA & Stationary & NA \\
\hline NITI & Non-Stationary & Stationary & Stationary & NA \\
\hline INTR & Stationary & NA & Stationary & NA \\
\hline BCA & Non-Stationary & Stationary & Non-Stationary & Stationary \\
\hline GDPR & Stationary & NA & Stationary & NA \\
\hline FTCH & Non- Stationary & Stationary & Non- Stationary & Stationary \\
\hline
\end{tabular}

The result of the unit root test as presented under Table 2 above reveals that our series are a mixture of variables integrated as $\mathrm{I}(0)$ and $\mathrm{I}(1)$ with no variables as $\mathrm{I}(2)$, hence, the panel ARDL will be most appropriate for

\footnotetext{
${ }_{1}^{1}$ The null hypothesis of the Hausman test is that the PMG is better than the MG and the DFE. we will accept the null hypothesis if the probability values from the Hausman h-test is more than $5 \%$ otherwise, we reject the null hypothesis.

2 Asteriou and Monastiriotis (2004) believes that the estimation will be inconsistent if some variables are I(2).
} 
this analysis. Moreover, the correlation analysis as presented in Tables 1A and $1 \mathrm{~b}$ under the Appendix section show that there is no case of perfect exactness among the variables. Therefore our model will not suffer from the multicollinearity problem, although the variables used to generate the index of financial technology was highly correlated; hence the need for an index for Fintechs rather than using each of the individual variables.

Moreover, the lag length structure ARDL $(1,1,1,1,1,1)$ was imposed on the variables based on the Schwarz information criterion. This is because our time dimension is not long enough to allow for higher degrees of freedom and for simplicity. Loayza and Ranciere (2006) and Demetriades and Siong (2006) asserts that lag structure can be imposed based on data limitation if the time dimension is not long enough to overstretch the lags.

\subsection{Results of the PMG, MG and DFE}

The result of the three estimator models (the PMG, MG and DFE) of the panel ARDL $(1,1)$ technique is presented under Table 3. With special emphasis on the PMG estimator due to the alignment of its assumptions with the data used in this study as explained below, the variable of interest which is the index of financial technology (FTCH) significantly dampens credit risk (NPL) up to a certain threshold after which it significantly raises it in the long-run with no significant short-run impact. Moreover, under DFE and MG estimators, FTCH likewise had a similar though insignificant impact on credit risk (NPL) both in the short and long-runs, except that there were no threshold effects for the MG in the long run.

Another important finding from the three estimators is that both bank-specific-Returns on Equity (ROE) and macroeconomic-economic growth (GDPR) determinants are negatively related with credit risk. Although that of growth was not significant, however, the prior expectation that higher growth and greater profit margin ultimately reduce the risk inherent in loan defaults is satisfied. Conversely, the PMG estimator shows that the non-interest income (NITI), a measure of diversification significantly increases credit risk in the long-run and reduces it in the short-run. While its long-run effect may be contrary to theoretical expectation, this finding reveals that the extent of banks' diversification among the BRICS economies could be another aspect of risk in the long run. The positive significant impact of interest rate suggests that the level of interest rate promotes loan defaults among borrowers. The models generally suggest that the system reverts or adjusts back to their long run steady-state at the average speed of $-31.9 \%,-61 \%$ and $-17.9 \%$ for the PMG, MG and the DFE estimators respectively after a potential contemporaneous disturbance (possibly from Fintechs) threatens the system. In other words, the short-run disequilibrium is corrected in the long-run at different speeds of adjustment for the three models.

The validity of three models was examined using the Hausman test. Meanwhile, since the PMG assumes strict homogeneity of the long-run slope coefficients across the entire cross sectional units $(\mathrm{N})$ but heterogeneity for the short-run coefficients, the intercept, and the long-run speed of adjustment to steady-state across the cross-sectional units $(\mathrm{N})$, it seems to be a better model for this study. This is because it aligns with our data and region of study. The Hausman h-test used to measure the models' comparative validity, efficiency and consistency as presented in Table 3, accepts the null hypothesis of the homogeneity restriction on the regressors in the long-run ${ }^{3}$. The heterogeneous assumption of all coefficients both in the long and short-runs by the MG estimator with a major weakness of inconsistent and inefficient estimation when the data series is not sufficiently large as is the case in our model, gives the PMG estimator upper advantage over the MG. Likewise, the restrictions imposed on the adjustment coefficient (ECT) and the short-run coefficients with specific intercepts for individual cross-sectional unit by the DFE estimator gives also lends credence to the PMG model as a better estimator especially as a longrun homogeneity is suggested among the regions under investigation as well as from the data characteristics. Moreover, the probability values of the Hausman h-test which are both greater than $5 \%$ significant levels suggests

\footnotetext{
${ }^{3}$ The null hypothesis is rejected if the probability value from the Hausman h-test is less than $5 \%$, otherwise we will accept $\mathrm{H}_{0}$
} 
that we cannot reject the null hypothesis of the presence of homogeneity among the regressors in the long run. Therefore, the Pooled Mean Group (PMG) estimator performs better than the MG and the DFE estimators.

Table-3. Results of the short-run and long-run dynamics of the ARDL $(1,1)$ estimation.

\begin{tabular}{|c|c|c|c|c|c|c|}
\hline \multirow[b]{2}{*}{ Variables } & \multicolumn{2}{|c|}{ Pooled Mean Group } & \multicolumn{2}{|c|}{ Mean Group } & \multicolumn{2}{|c|}{ Dynamic Fixed Effect } \\
\hline & Coef. & Std Error & Coef. & Std Error & Coef. & Std Error \\
\hline \multicolumn{7}{|l|}{ Long-Run } \\
\hline $\mathrm{ROE}_{\mathrm{t}-1}$ & $-0.133 * * *$ & 0.039 & -0.463 & 0.368 & $-0.789^{* * * *}$ & 0.303 \\
\hline NITI $_{t-1}$ & $0.213 * * *$ & 0.023 & -0.275 & 0.227 & 0.213 & 0.151 \\
\hline $\mathrm{INTR}_{\mathrm{t}-1}$ & $0.098 * *$ & 0.046 & 2.237 & 1.545 & -0.112 & 0.206 \\
\hline $\mathrm{GDPR}_{\mathrm{t}-1}$ & -0.027 & 0.099 & $-0.900 *$ & 0.529 & -0.450 & 0.691 \\
\hline $\mathrm{FTCH}_{\mathrm{t}-1}$ & $-2.256^{* * *}$ & 0.477 & -0.460 & 1.099 & -2.041 & 1.961 \\
\hline FTCHsq $_{\mathrm{t}-1}$ & $1.598 * * *$ & 0.219 & -0.324 & 0.865 & 0.539 & 0.916 \\
\hline \multicolumn{7}{|l|}{ Short-Run } \\
\hline ECT & $-0.319^{* *}$ & 0.156 & $-0.610^{* * *}$ & 0.220 & $-0.179^{* * *}$ & 0.056 \\
\hline$\triangle \mathrm{ROE}$ & -0.024 & 0.029 & -0.106 & 0.075 & $-0.101^{* * * *}$ & 0.038 \\
\hline$\Delta$ NITI & -0.096 & 0.152 & -0.120 & 0.142 & $0.088^{* * *}$ & 0.042 \\
\hline$\triangle \mathrm{INTR}$ & 0.146 & 0.103 & 0.630 & 0.507 & 0.014 & 0.061 \\
\hline$\triangle \mathrm{GDPR}$ & -0.067 & 0.077 & 0.170 & 0.153 & -0.072 & 0.098 \\
\hline$\triangle \mathrm{FTCH}$ & 2.239 & 1.528 & 2.141 & 1.453 & -0.028 & 1.358 \\
\hline$\Delta \mathrm{FTCHsq}$ & 1.129 & 0.867 & 0.427 & 1.237 & -0.075 & 0.460 \\
\hline Intercept & -2.546 & 1.547 & 1.803 & 3.566 & 2.027 & 1.674 \\
\hline Observation (Group) & $120(5)$ & & $120(5)$ & & $120(5)$ & \\
\hline
\end{tabular}

Hausman Test: $\mathrm{H}_{0}$ : PMP is efficient estimation than MG h-test $=3.98$; Probability Value $=0.680^{4}$

Hausman Test: $\mathrm{H}_{0}$ : PMP is efficient estimation than DFE h-test $=4.32$; Probability Value $=0.074^{5}$

*** significance at $1 \%$, ** significant at $5 \%$, and $*$ significant at $10 \%$

Note: Hausman Test: $\mathrm{H}_{0}$ : PMP is efficient estimation than MG h-test $=3.98$; Probability Value $=0.680^{6}$

Hausman Test: $\mathrm{H}_{0}:$ PMP is efficient estimation than DFE h-test $=4.32$; Probability Value $=0.074^{7}$

**** significance at $1 \%, * *$ significant at $5 \%$, and $*$ significant at $10 \%$.

\subsection{The Dynamic Difference GMM and the Static FE and RE Models}

We employed the dynamic difference GMM and the Static fixed effect and random effect models to substantiate the findings from the PMG, MG and DFE estimators of the ARDL model. The essence of this is necessitated because of the peculiar weaknesses inherent in sticking to a particular model, which can be circumvented when more than one estimation method is used.

The findings from the difference GMM, fixed effect and random effect models affirm consistent result with the ARDL $(1,1)$ PMG, MG and the DFE estimators. They show that the variable of interest which is the index of financial technology (FTCH) significantly dampens credit risk in the short run up to a certain threshold after which it increases it in the long-run. The consistency of this result both with a dynamic model and a static model suggests the presence of an inverted U-shape effect of Fintechs on credit risk. Other significant regressors as presented under Table 4 below follow prior expectation. However, the main weakness of this model, particularly, the difference GMM result is that the instrumental variables are weak because the P-value is less than $5 \%$.

\subsection{Test of the Sasabuchi-Lind-Mehlum Test for Inverse U-Shaped Relationship.}

This test aims to further verify our findings from the PMG, GMM and static models of the fixed and random effects that the relationship between financial technology and credit risk is non-linear. Many authors have investigated this relationship with respect to financial development and growth (Samargandi et al., 2015) income

\footnotetext{
${ }^{4}$ Where the null hypothesis is that the PMG is efficient estimator than MG estimator.

${ }^{5}$ Where the null hypothesis is that the PMG is efficient estimator than DFE estimator.

${ }^{6}$ Where the null hypothesis is that the PMG is efficient estimator than MG estimator.

${ }^{7}$ Where the null hypothesis is that the PMG is efficient estimator than DFE estimator.
} 
and inequality (Kuznets, 1955) and between income and pollution (Grossman \& Krueger, 1995) to mention a few. We follow this approach to investigate this relationship with respect to financial technology and credit risk. To the best of my knowledge, no study has assessed this relationship.

Table-4. The Dynamic GMM and the static FE and RE models for robustness check.

\begin{tabular}{|c|c|c|c|c|}
\hline L. NPL & 0.888 & GDPR & -0.057 & 0.426 **** \\
\hline & $(9.57)^{* * * *}$ & & $(0.33)$ & $(2.71)$ \\
\hline L2. NPL & -0.265 & $\mathrm{ROE}$ & $-0.196^{* * * *}$ & $-0.255^{* * * *}$ \\
\hline & $(3.02)^{* * * *}$ & & $(3.35)$ & $(3.84)$ \\
\hline L. GDPR & 0.062 & NITI & $0.141^{* * * *}$ & $0.124^{* * * *}$ \\
\hline & $(0.64)$ & & $(3.28)$ & $(3.48)$ \\
\hline L. ROE & -0.051 & INTR & -0.047 & $0.081^{* * * *}$ \\
\hline & $(1.45)$ & & $(0.78)$ & $(5.18)$ \\
\hline NITI & 0.054 & FTCH & $-3.010^{* * * *}$ & $-2.106^{* * * *}$ \\
\hline & $(1.96)^{* *}$ & & $(6.16)$ & $(5.37)$ \\
\hline INTR & -0.026 & FTCHsq & $0.496^{* *}$ & $0.833^{* * *} *$ \\
\hline & $(0.76)$ & & $(2.04)$ & $(3.43)$ \\
\hline FTCH & -1.099 & $\mathrm{BCA}$ & $-1.272^{* * * *}$ & $-1.245^{* * * *}$ \\
\hline & $(2.89)^{* * * *}$ & & $(4.12)$ & $(5.18)$ \\
\hline FTCHsq & 0.388 & Constant & $15.397^{* * * *}$ & $11.077^{* * * *}$ \\
\hline & $(2.54)^{* *}$ & & $(4.67)$ & $(4.87)$ \\
\hline BCA & -0.780 & R-squared & 0.53 & 0.44 \\
\hline & $(4.49)^{* * *}$ & & & \\
\hline $\mathrm{AR} 2$ & P-Value $=0.195$ & \multirow{2}{*}{\multicolumn{3}{|c|}{$\begin{array}{c}\text { Hausman Test:Random Effect is better: h-Test } \\
\qquad=227.45 ; \mathrm{P}-\mathrm{V} \text { alue }=0.0000\end{array}$}} \\
\hline Sergan Test & P-Value $=0.014$ & & & \\
\hline No of Obs (No of Group) & $84(4)$ & & $120(5)$ & $120(5)$ \\
\hline
\end{tabular}

We modeled a quadratic equation on the relationship between NPL and FTCH (i.e. FTCHsq or FTCH² ) in the panel ARDL model as presented in Table 3 above and Table 4 where FTCH had a significant negative impact on credit risk (NPL), while $\mathrm{FTCH}^{2}$ (i.e. FTCHsq) had a significant positive relationship with credit risk. The implication of this is that too many Fintechs adoption will increase credit risk in the near future. Therefore, while the marginal effect of Fintechs adoption will help reduce credit risk up to a certain threshold after which further adoptions will significantly increase it beyond a particular threshold. Hence too many Fintechs adoption can generate future bank crisis. To justify this assertion, we conducted the U test of Lind and Mehlum (2010). To do this, we re-specify Equation 1 above in its reduced form model for the sake of simplicity and clarity of purpose thus:

$$
N P L_{i t}=\alpha+\delta_{i} F T C H_{i t}+\lambda f\left(F T C H_{i t}\right)+\xi^{\prime} x_{i t}+\varepsilon_{i t}
$$

Equation 2 is the reduced form nonlinear relationship between credit risk and Fintech of Equation 1 above. Here the variables are as defined above, $x_{i t}$ is a vector of control variables. The function $f$ depends on the parameters $\delta$ and $\lambda$. Equation 2 may be a U-shape relationship or not with the assumption that it has only one extreme point. Hence the relationship is either $\mathrm{U}$ shaped or monotone. The term $\delta_{i} F T C H_{i t}$ represents the linear relationship between credit risk and Fintech whereas the term $\lambda_{j} f\left(F T C H_{i t}\right)$ represents its nonlinear (turning-point) relationship. The assumption of a $\mathrm{U}$ shape is that the slope of the curve is negative at the beginning and turns to positive after a reasonable point. The null and alternative hypotheses are stated thus:

$$
\mathrm{H}_{0}: \delta_{\mathrm{i}}+\lambda \mathrm{f}^{\prime}\left(\mathrm{FTCH}_{\text {lower bound }}\right) \geq 0 \text { and/or } \delta_{\mathrm{i}}+\lambda \mathrm{f}^{\prime}\left(\mathrm{FTCH}_{\text {upper bound }}\right) \leq 0
$$

This can be rejected in favour of the alternative hypothesis stated thus:

$$
\mathrm{H}_{1}: \delta_{\mathrm{i}}+\lambda \mathrm{f}^{\prime}\left(\mathrm{FTCH}_{\text {lower bound }}\right)<0 \text { and } / \text { or } \delta_{\mathrm{i}}+\lambda \mathrm{f}^{\prime}\left(\mathrm{FTCH}_{\text {upper bound }}\right)>0
$$

Equations 3 and 4 are the null hypothesis of an inverted $U$ shaped/monotonic assumption to be tested against the alternative hypothesis of a $\mathrm{U}$ shaped assumption respectively. Here, $\mathrm{FTCH}_{\text {lower bound }}$ and $\mathrm{FTCH}_{\text {upper bound }}$ represent the minimum and maximum values of financial technology respectively. The decision rule is to reject the null 
hypothesis of monotonic/inverse $\mathrm{U}$ shape if either $H_{o}$ lower bound or $H_{o}$ upper bound or both can be rejected at a given level of confidence $(\alpha=0.05)$. Therefore from our Table 5 below, we can see that $H_{o}$ lower bound is significantly negative whereas the $H_{o}$ upper bound is significantly positive at $5 \%$ level of significance suggesting the presence of a $\mathrm{U}$ shape relationship between financial technology (FTCH) and credit risk (NPL). Hence the null hypothesis of inverse $\mathrm{U}$ shape is rejected in favour of the alternative.

Table-5. The results of the Sasabuchi-Lind-Mehlum test for U-shaped relationship.

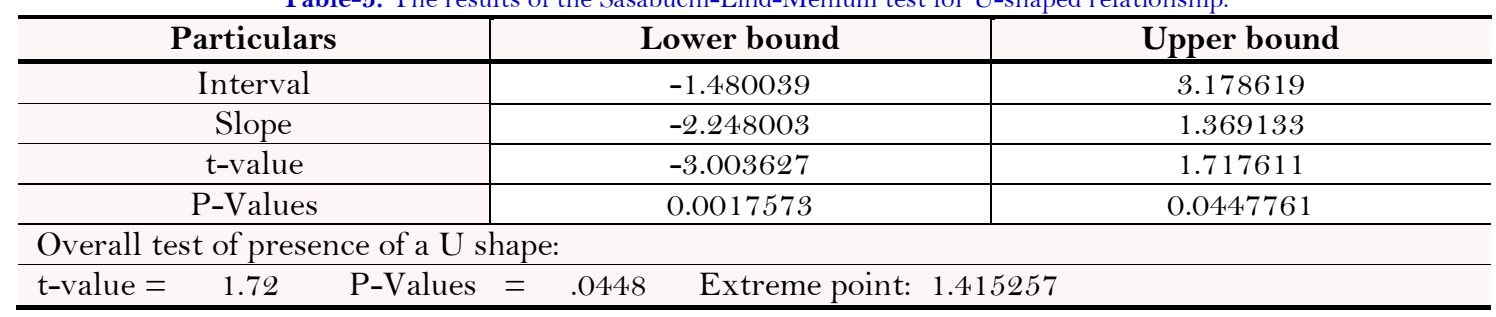

\section{CONCLUSION AND POLICY IMPLICATION}

Studies on credit risk determinants have focused on the impact of macroeconomic and bank-specific variables on it. Empirical evidence has revealed that even in the midst of a stable macroeconomic and financial system, banks still face increased credit risk problems especially in this modern era of Fintechs adoption. This study therefore investigates whether financial technology will culminate into bank credit crisis among high Fintechs adoption BRICS economies. We employed an advanced econometric estimation techniques of panel ADRL $(1,1)$ model under three estimation tools of pooled mean group (PMG), mean group (MG), and dynamic fixed effect (DFE) to investigate this relationship. Our findings from the more efficient and consistent results of the PMG estimator based on the Hausman test show that financial technology dampens credit risk in the short-run but increases it after a threshold of its adoption is reached in the long-run. This suggests the existence of a non-linear relationship between Fintechs and credit risk. Moreover, a consistent result with other empirical findings such as the works of Louzis et al. (2012); Castro (2013) and Chaibi and Ftiti (2015) were found, that both bank-specific variable (Bank profitability) and macroeconomic factor (Growth rate) dampens credit risk while interest rate and bank diversification (non-interest income) raises it.

As a robustness check, we also applied the dynamic difference GMM and static fixed and random effects technique to verify our findings. Their results revealed consistent results with that from the pooled mean group (PMG) estimator. We also investigated the non-linear/monotonic relationship of financial technology with credit risk using the Lind and Mehlum (2010) U-test to obtain sufficient prove for the existence of a U relationship. Our finding supports the affirmation that financial technology and credit risk have a non-linear relationship.

We therefore conclude that aside from bank specific/microeconomic and macroeconomic variables that can potentially drive credit risk, countries should guide against excessive Fintechs adoption as it may pose a potential banking crisis especially when banks and financial technology companies do not collaborate. Therefore, while we recommend that financial regulators and policymakers should optimize the right financial technology adoption rate to be undertaken in an economy, Fintech's collaboration with banks should be encouraged. We also suggest that further studies on this relationship should consider the heterogeneous nature of economic structures, financial systems, political atmosphere, and institutional qualities among countries that might hamper or accelerate this relationship.

Funding: This study received no specific financial support.

Competing Interests: The author declares that there are no conflicts of interests regarding the publication of this paper. 


\section{REFERENCES}

Agnello, L., \& Sousa, R. (2011). How do banking crises impact on income inequality? NIPE Working Papers, WP 30/2011. University of Minho.

Ahmad, N. H., \& Ariff, M. (2007). Multi-country study of bank credit risk determinants. International Journal of Banking and Finance, 5(1), 135-152.

Ali, A., \& Daly, K. (2010). Macroeconomic determinants of credit risk: Recent evidence from a cross country study. International Review of Financial Analysis, 19(3), 165-171.Available at: https://doi.org/10.1016/j.irfa.2010.03.001.

Altıntas, A. (2012). Estimation of credit losses based on macroeconomic variables and stress tests. For the Turkish banking sector an econometric approach (An econometric approach for Turkish banking (Vol. 281). Istanbul: The Banks Association of Turkey.

Arellano, M. (2003). Panel data econometrics: Oxford University Press. Retrieved from: https://books.google.co.za/books?hl=en\&lr=\&id=LoDnCwAAQBAJ\&oi=fnd\&pg=PR7\&dq=Arellano,+M.+(2003):+ Panel+Data+Econometrics, + Oxford+University+Press\&ots=PXSALMHmon\&sig=9DGoSQ7PrZiST1MKDanTdBS uw6k\&redir_esc=y\#v=onepage\&q=Arellano\%2C\%20M.\%20(2003)\%3A\%20Panel\%20Data\%20Econometrics\%2C\%20 Oxford\%20University\%20Press\&f=false. [Accessed 12th September, 2019].

Asteriou, D., \& Monastiriotis, V. (2004). What do unions do at the large scale? Macro-economic evidence from a panel of OECD countries. Journal of Applied Economics, 7(1), 27-46.

Aver, B. (2008). An empirical analysis of credit risk factors of the Slovenian banking system. Managing Global Transitions, 6(3), 317-334.

Berger, A. N., \& DeYoung, R. (1997). Problem loans and cost efficiency in commercial banks. Journal of Banking and Finance, $21(6), 849-870$.

Bohachova, O. (2008). The impact of macroeconomic factors on risks in the banking sector: A cross country empirical assessment. IAW Discussion Papers, No. 44.

Bonfim, D. (2009). Credit risk drivers: Evaluating the contribution of firm level information and of macroeconomic dynamics. Journal of Banking \& Finance, 33(2), 281-299.Available at: https://doi.org/10.1016/j.jbankfin.2008.08.006.

Campos, N. F., \& Kinoshita, Y. (2010). Structural reforms, financial liberalization, and foreign direct investment. IMF Staff Papers, 57(2), 326-365.Available at: https://doi.org/10.1057/imfsp.2009.17.

Castro, V. (2013). Macroeconomic determinants of the credit risk in the banking system: The case of the GIPSI. Economic Modelling, 31, 672-683.Available at: https://doi.org/10.1016/j.econmod.2013.01.027.

Chaibi, H., \& Ftiti, Z. (2015). Credit risk determinants: Evidence from a cross-country study. Research in International Business and Finance, 33, 1-16.Available at: https://doi.org/10.1016/j.ribaf.2014.06.001.

Demetriades, P., \& Siong, H. L. (2006). Finance, institutions and economic growth. International Journal of Finance and Economics, $11(3), 245-260$.

Demirgüç-Kunt, A., \& Detragiache, E. (1998). The determinants of banking crises in developing and developed countries. Staff Papers, 45(1), 81-109.

Ernest, \& Young. (2017). EY FinTech Adoption Index. The rapid emergence of FinTech. Retrieved from http://www.ey.com/Publication/vwLUAssets/ey-fintech-adoption-index-2017/\$FILE/ey-fintech-adoption-index2017.pdf. [Accessed April 17th, 2018].

Festic, M., Kavkler, A., \& Repina, S. (2011). The macroeconomic sources of systemic risk in the banking sectors of five new E U member states. Journal of Banking \& Finance, 35(2), 310-322.

Grossman, G. M., \& Krueger, A. B. (1995). Economic growth and the environment. The Quarterly Journal of Economics, $110(2)$, 353-377.

Jakubík, P. (2007). Macroeconomic environment and credit risk. Czech Journal of Economics and Finance, 57(1-2), 60-78.

Kattai, R. (2010). Credit risk model for the Estonian banking sector. Bank of Estonia Working Papers, No.1.

Kuznets, S. (1955). Economic growth and income inequality. The American Economic Reviere, 45(1), 1-28. 
Lind, J. T., \& Mehlum, H. (2010). With or without U? The appropriate test for a U-shaped relationship. Oxford Bulletin of Economics and Statistics, 72(1), 109-1 18.Available at: https://doi.org/10.1111/j.1468-0084.2009.00569.x.

Llewellyn, D. T. (2002). An analysis of the causes of recent banking crises. The European Journal of Finance, 8(2), 152-175.

Loayza, N. V., \& Ranciere, R. (2006). Financial development, financial fragility, and growth. Journal of Money, Credit and Banking, 38(4), 1051-1076.

Louzis, D. P., Vouldis, A. T., \& Metaxas, V. L. (2012). Macroeconomic and bank-specific determinants of nonperforming loans in Greece: a comparative study of mortgage, business and consumer loan portfolios. Journal of Banking and Finance, 36(4), $1012-1027$.

Messai, A. S., \& Jouini, F. (2013). Micro and macro determinants of non-performing loans. International Journal of Economics and Financial Issues, 3(4), 852-860.

Nkusu, M. (2011). Nonperforming loans and macro-financial vulnerabilities in advanced economies. International Monetary Fund (IMF), No. 11-161.

Pesaran, M. H., \& Smith, R. (1995). Estimating long-run relationships from dynamic heterogeneous panels. Journal of Econometrics, 68(1), 79-113.Available at: https://doi.org/10.1016/0304-4076(94)01644-f.

Pesaran., M. H., Shin, Y., \& Smith, R. P. (1999). Pooled mean group estimation of dynamic heterogeneous panels. Journal of the American Statistical Association, 94(446), 62 1-634.Available at: https://doi.org/10.1080/0162 1459.1999.10474156.

Podpiera, J., \& Weill, L. (2008). Bad luck or bad management? Emerging banking market experience. Journal of Financial Stability, 4(2), 135-148.Available at: https://doi.org/10.1016/j.jfs.2008.01.005.

Roodman, D. (2006). How to do xtabond2: An introduction to "difference" and "system" GMM in Stata. Working Paper, No. 103 December 2008, Centre for Global Development.

Salas, V., \& Saurina, J. (2002). Credit risk in two institutional regimes: Spanish commercial and savings banks. Journal of Financial Services Research, 22(3), 203-224.

Samargandi, N., Fidrmuc, J., \& Ghosh, S. (2015). Is the relationship between financial development and economic growth monotonic? Evidence from a sample of middle-income countries. World Development, 68, 66-81.Available at: https://doi.org/10.1016/j.worlddev.2014.11.010.

South Africa Reserve Bank. (2016). Financial stability Retrieved from: https://www.resbank.co.za/Financial\%20Stability/Pages/FinancialStability-Home.aspx. [Accessed 10/03/2017].

Zribi, N., \& Boujelbegrave, Y. (2011). The factors influencing bank credit risk: The case of Tunisia. Journal of Accounting and Taxation, 3(4), 70-78.

\section{APPENDIX}

Table-1A. Pairwise correlation analysis (obs=120).

\begin{tabular}{c|c|c|c|c|c|c|c|c}
\hline & NPL & GDPR & LINTR & NITI & ROE & BCA & FTCH & FTCHsq \\
\hline NPL & 1.0000 & & & & & & & \\
\hline GDPR & 0.1649 & 1.0000 & & & & & & \\
\hline LINTR & -0.0328 & -0.4346 & 1.0000 & & & & & \\
\hline NITI & -0.1067 & -0.5467 & 0.0808 & 1.0000 & & & & \\
\hline ROE & -0.2099 & 0.3080 & -0.0987 & -0.1647 & 1.0000 & & & \\
\hline BCA & -0.3518 & -0.4443 & 0.4621 & 0.6041 & -0.1514 & 1.0000 & & \\
\hline FTCH & -0.4210 & -0.1558 & -0.0927 & 0.1430 & -0.0074 & 0.1802 & 1.0000 & \\
\hline FTCHsq & -0.0587 & -0.0822 & -0.0633 & 0.0046 & -0.0264 & 0.0729 & 0.5950 & 1.0000 \\
\hline
\end{tabular}

Table-1B. Pairwise correlation analysis among the component variables (obs=120).

\begin{tabular}{l|c|c|c}
\hline & ITB & MCS & ATM \\
\hline Individuals Using Internet to Total Population (ITB) & 1.0000 & & \\
\hline Mobile Cellular Subscription (MCS) & 0.3905 & 1.0000 & \\
\hline Automated Teller Machine (ATM) & 0.8472 & 0.8109 & 1.0000 \\
\hline
\end{tabular}


Lag Length Criterion

Included observations: 100

\begin{tabular}{c|c|c|c|c|c|c}
\hline Lag & LogL & LR & FPE & AIC & SC & HQ \\
\hline 0 & -291.5381 & NA & 22.94533 & 5.970762 & 6.153124 & 6.044567 \\
\hline 1 & -210.0456 & 149.9462 & 4.587694 & 4.360912 & $4.569326^{*}$ & 4.445261 \\
\hline 2 & -202.5022 & 13.72895 & 4.025526 & 4.230044 & 4.464510 & 4.324937 \\
\hline 3 & -199.4047 & $5.575452^{*}$ & 3.860854 & 4.188095 & 4.448612 & 4.293531 \\
\hline 4 & -197.2964 & 3.752809 & $3.777057^{*}$ & $4.165928^{*}$ & 4.452497 & $4.281908^{*}$ \\
\hline
\end{tabular}

Views and opinions expressed in this article are the views and opinions of the author(s), Asian Economic and Financial Review shall not be responsible or answerable for any loss, damage or liability etc. caused in relation to/arising out of the use of the content. 